\title{
ELUCIDATING THE ROLE OF THE SATB1 GENE IN BREAST CANCER CARCINOGENESIS IN THE PRESENCE OR ABSENCE OF TOCOTRIENOL-RICH FRACTION: EVIDENCE FROM A SYNGENEIC MOUSE MODEL OF BREAST CANCER
}

\author{
SITTI RAHMA ABDUL HAFID ${ }^{1,2^{*}}$ and AMMU KUTTY RADHAKRISHNAN ${ }^{3,4}$ \\ ${ }^{1}$ Malaysian Palm Oil Board, 6 Persiaran Institusi, Bandar Baru Bangi, \\ 43000 Selangor, Malaysia \\ ${ }^{2}$ School of Postgraduate Studies, International Medical University, \\ 126 Jalan 19/155B, Bukit Jalil, 57000 Kuala Lumpur, Malaysia \\ ${ }^{3}$ Pathology Division, School of Medicine, International Medical University, \\ 126 Jalan 19/155B, Bukit Jalil, 57000 Kuala Lumpur, Malaysia \\ ${ }^{4}$ Jeffrey Cheah School of Medicine and Health Sciences, Monash University Malaysia, \\ Jalan Lagoon Selatan, 47500 Bandar Sunway, Selangor Darul Ehsan, Malaysia \\ *E-mail: ctrahma@mpob.gov.my
}

Accepted 13 December 2021, Published online 31 December 2021

\begin{abstract}
Tocotrienols are reported to possess anticancer activities. Recently we showed that the anticancer effects of tocotrienolrich fraction (TRF) may be through inhibition of the special AT-rich sequence-binding protein 1 (SATB1) gene in a syngeneic mouse model of breast cancer (BC). The present study aims to further explore the role of the SATB1 gene in murine BC cells. The expression of the SATB1 gene in the 4T1 murine BC cells was partially knocked down (SATB1-4T1) using the short hairpin RNA (shRNA) technology and these cells were injected into the mammary pads of mice. Control groups were injected with wild-type 4T1 (WT 4T1) cells. When the tumour was palpable, half of the mice in both groups were fed daily with $1 \mathrm{mg}$ TRF and received intraperitoneal injections of dendritic cells pulsed with tumour lysate (DC+TL) once a week for three weeks. The tumour incidence in mice injected with the SATB1-4T1 cells was reduced $(p<0.05)$ and this effect was independent of TRF supplementation. However, in mice injected with WT-4T1, there was inhibition of tumour growth $(p<0.05)$ only in the group fed with TRF. In addition, the expression of S1004A and mutant P53 genes were suppressed in tumours from animals that were injected with the SATB1-4T1 cells, irrespective of TRF supplementation; which was also observed in tumours from mice injected with WT 4T1 cells and fed with TRF. These findings suggest that TRF may work through the SATB1 pathway.
\end{abstract}

Key words: Breast cancer, dendritic cell vaccine, knockdown shRNA, SATB1 gene, tocotrienol-rich fraction

\section{INTRODUCTION}

Breast cancer $(\mathrm{BC})$ is the most common cancer among women, affecting 2.1 million women yearly and causing the most significant number of cancerrelated deaths. In 2018, it was estimated that as many as 627,000 or $15 \%$ of women died from BC. The BC rates are higher among women in more urban areas and are increasing worldwide (World Health Organization [WHO], n.d.). The pathophysiology of cancer is a complicated process as this involves several gene-environment interactions that

\footnotetext{
* To whom correspondence should be addressed.
}

sequentially take place, that may affect multiple physiological pathways resulting in aberrant gene expression that can promote tumour development. Fighting tumours is one of the host immune system's natural roles; it may be more efficacious to develop newer therapies that can stimulate the immune system to fight cancer. Some of the immune-enhancing approaches that have anticancer activities include the use of antioxidants (Nesaretnam et al., 2012), biologics monoclonal antibodies, a healthy lifestyle and cancer vaccines (Nesaretnam et al., 2012). Some of these approaches might help curb the alarming rise in $\mathrm{BC}$ cases. Tocotrienol rich-fraction (TRF) is a 
naturally occurring form of vitamin E, which has been reported to induce apoptosis in various cancer cells in cell-based and animal studies (Abdul-Hafid et al., 2019; Aggarwal et al., 2019).

Tocotrienols belong to the vitamin E family. Vitamin E consists of two structurally similar compounds called tocopherols and tocotrienols. Tocotrienols are considered more potent than tocopherols and are promising anticancer agents due to their potent effects against many cancers (Ling et al., 2012). Several cell-based and animal model studies have shown that palm TRF possessed antitumour properties in prostate, breast, skin, colon, stomach, pancreatic, liver and lung cancers through apoptosis, anti-angiogenesis, anti-proliferative and immunoregulation (Parveez et al., 2019; Abdul-Hafid et al., 2019; Aggarwal et al., 2019). Studies conducted by researchers showed that tocotrienols possessed several anticancer properties that made them superior to tocopherols (Ling et al., 2012; Wong et al., 2020). These include inhibiting epithelial-to-mesenchymal transitions (EMT), suppressing vascular endothelial growth factor (VEGF) tumour angiogenic pathway and anti-tumour immunity induction (Ling et al., 2012). In other studies, TRF had shown to have chemo-sensitization and anti-cancer stem cell effects, which further demonstrated the potential of TRF as an effective anticancer therapeutic agent (Zhang et al., 2015; Ahmed et al., 2016; Abd-Hafid et al., 2020). The anti-tumour effects of tocotrienols facilitated through the suppression of metastatic phenotypes.

TRF supplementation in combination with subcutaneous injection of dendritic cells pulsed with tumour lysate (DC+TL) from murine mammary cells inhibited tumour growth and metastasis in a syngeneic mouse model of breast cancer (BC) (Abdul-Hafid et al., 2010). In addition, splenocytes from the DC+TL+TRF mice cultured with mitomycin$\mathrm{C}$ (MMC)-treated 4T1 cells produced higher levels of interferon-gamma (IFN- $\gamma$ ) and interleukin-12 (IL12), and tumour-specific cytotoxic T-lymphocyte (CTL) responses (Abdul-Hafid et al., 2013). Recently it was reported that the expression of the special ATrich sequence-binding protein 1 (SATB1) gene was significantly reduced in tumours from mice in the $\mathrm{DC}+\mathrm{TL}+\mathrm{TRF}$ group compared to the tumour from control, DC alone or DC+TL groups (Abdul-Hafid et al., 2019). To investigate the expression and mechanisms of the $S A T B 1$ gene in this animal model of BC, we knocked down the expression of the SATB1 gene in the 4T1 cells to investigate the role of this gene in tumour growth and metastasis using the same animal model.

The SATB1 gene expression in the 4T1 cells was knocked down using the RNA interference (RNAi), specifically the short hairpin RNA (shRNA) approach, which is a new strategy that offers several advantages for treating cancers. RNAi-based therapeutics have been widely used to knock down some of the cancer-associated genes, and this is a simple approach that utilizes rapid design and synthesis with a higher degree of specificity to target tumour cells and inhibit expression of the target gene (Zhang \& Huang, 2014). The shRNA strategy is used to silence genes related to tumour growth, invasion, angiogenesis, metastasis and chemoresistance in various cancer types (Deng et al., 2014). The primary targets for this RNAi-based therapy are oncogenes, mutated tumour suppressor genes, survival or apoptotic genes and genes that initiate tumour progression (Abdurakhmonov, 2016). As a single therapeutic strategy is usually insufficient to inhibit tumour growth and progression, it would be better to use combination therapies such as RNAi with chemotherapy, radiotherapy, anti-hormone therapy, or immunotherapy to achieve a synergistic therapeutic effect (Şalva et al., 2016).

The overall objective of the current study is to investigate the protective role of the $S A T B 1$ gene in tumorigenesis using SATB1-4T1 cells in a syngeneic mouse model of BC. Another objective of this study is to compare the effect of reduced gene expression of SATB1 in the mice treated with DC+TL+TRF.

We hypothesise that there will be reduced tumour growth in animals that were injected with SATB1-4T1 cells compared to those that were injected with WT-4T irrespective of TRF supplementation. We also hypothesise that knocking down the SATB1 gene will affect the expression of key genes related to tumorigeneses such as the $S 1004 A$ and mutant $p 53$ genes in the tumours excised from these animals.

\section{MATERIALS AND METHODS}

\section{Short hairpin RNA}

The short hairpin RNA (shRNA) was produced using the Sure Silencing shRNA kit as recommended by the manufacturer (QIAGEN, Germany). There are four types of shRNA samples and one negative control in the shRNA kit.

\section{Preparation of LB broth and LB agar}

Luria Bertani (LB)-ampicillin broth was prepared by mixing and dissolving $25 \mathrm{~g}$ LB (Sigma, USA) in $1000 \mathrm{~mL}$ of distilled water and autoclaved. Once cooled to room temperature, $1 \mathrm{~mL}$ ampicillin solution (50 mg/mL) (Gibco, USA) was added to the LB broth solution. For LB-ampicillin agar preparation, $25 \mathrm{~g}$ of $\mathrm{LB}$ and $15 \mathrm{~g}$ of agar was mixed in $1000 \mathrm{~mL}$ of distilled water and autoclaved. Once cooled to $50{ }^{\circ} \mathrm{C}, 1 \mathrm{~mL}$ ampicillin solution $(50 \mathrm{mg} / \mathrm{mL})$ was added to the LB broth-agar solution. The broth was then poured into 
a petri dish and left at room temperature for $1-2 \mathrm{~h}$ to allow the agar to solidify. The set plates were stored at $4{ }^{\circ} \mathrm{C}$ until further use.

Transformation of shRNA plasmids using competent bacterial cells

Commercial source of the JM109 (E. coli) competent cells (Sigma Aldrich, USA) was used. Beforehand, the competent cells stored at $-80{ }^{\circ} \mathrm{C}$ were thawed and transferred to appropriately labelled RNAse-free tubes $(100 \mu \mathrm{L} /$ tube $)$. After that, the four types of shRNAs $(10 \mu \mathrm{L}$ each) were added into the labelled tubes containing the competent cells. The mixture was gently mixed and immediately incubated on ice for $10 \mathrm{~min}$. After that, the cells were subjected to heat shock by incubation at $42{ }^{\circ} \mathrm{C}$ in a water bath for $50 \mathrm{~s}$ before placing them on ice for $2 \mathrm{~min}$. Subsequently, $900 \mu \mathrm{L}$ of cold Super Optimal Broth with Catabolite Repression (SOC) medium was added to each tube with the transformation reaction, and the tubes were incubated at $37{ }^{\circ} \mathrm{C}$ with a shaking incubator (approximately 225 r.p.m.) for $60 \mathrm{~min}$. The cells were then diluted $(1: 10,1: 100)$ using LBampicillin broth and $100 \mu \mathrm{L}$ from each dilution, which was used to plate on LB-ampicillin agar plates. The plates were incubated at $37^{\circ} \mathrm{C}$ for $14 \mathrm{~h}$.

\section{Isolation and quantification of Plasmid DNA}

After $14 \mathrm{~h}$ of incubation, single colonies were picked from the LB-ampicillin plates and aseptically inoculated into a tube containing $5 \mathrm{~mL}$ of LBampicillin broth. The starter culture was incubated for eight hr at $37{ }^{\circ} \mathrm{C}$ with vigorous shaking (300 r.p.m.). After that, the starter culture was aseptically transferred to a conical flask containing $250 \mathrm{~mL}$ of LB-ampicillin broth and incubated overnight in a shaking (225 r.p.m.) incubator (New Brunswick, Germany). The bacterial cells were recovered by centrifugation (4000 r.p.m. for $20 \mathrm{~min}$ at $4{ }^{\circ} \mathrm{C}$ ), and the plasmid DNA was extracted using a plasmid DNA extraction kit (QIAGEN, Germany). The plasmid DNA concentration was quantified using the NanoDrop Agilent 2000, set to DNA nucleic acid.

\section{Transfection of shRNA plasmid into 4T1 cells}

\section{Preparation of cells before transfection}

The 4T1 murine mammary cells were cultured in a T75 flask with RPMI complete medium and incubated at $37{ }^{\circ} \mathrm{C}$ with $5 \% \mathrm{CO}_{2}$ in an incubator until the cells were confluent. The cells were harvested by centrifugation and washed once with sterile phosphate-buffered saline (PBS) before the cells were re-suspended in RPMI complete medium $(8 \times 106$ cells in $24 \mathrm{~mL}$ of culture medium). Then, $4 \mathrm{~mL}$ of these cells were aliquoted into six appropriately labelled $15 \mathrm{~mL}$ tubes (Falcon, USA). One of the six tubes containing the 4T1 cells was used as control and named 4T1 control. The 4T1 control tube contents were dispensed into eight $(0.5 \mathrm{~mL}$ per well) wells of a 24-well plate (Nunc Inc., Germany). The cells in the remaining five tubes were treated with plasmid and transfection reagent before plating, similar to the 24-well plates.

\section{Transfection of shRNA plasmid into $4 T 1$ cells}

As described above, six samples had DNA plasmids for the shRNA step; one is for a negative control of shRNA, and the sixth tube is the 4T1 control. Two 24-well plates were used for this part of the experiment. For each sample, eight wells were used. The transfection step was carried out for all these samples, except for the 4T1 control. Before the transfection step, $476.80 \mu \mathrm{L}$ of the Opti-Mem medium (Invitrogen, USA) was prepared for each sample. The DNA plasmids were added to the respective tube containing the Opti-Mem medium (Supplement 1), and the tubes were rocked gently. Then, $24 \mu \mathrm{L}$ of the Attractane transfection reagent (QIAGEN, Germany) was added to each sample. The mixture was incubated at room temperature for $15 \mathrm{~min}$ on a rocking shaker. At the end of the incubation period, $0.5 \mathrm{~mL}$ of this mixture (attractant-plasmid complexes) was added into each tube containing the cells and mixed. The cells mixed with the DNA plasmids (shRNA) were dispensed into each well ( 8 wells for each sample containing $1 \mathrm{~mL}$ of cell mixture). For 4T1 control cells, $0.5 \mathrm{~mL}$ of complete medium was added to each well (Supplement 2). The plates were then incubated overnight at $37{ }^{\circ} \mathrm{C}$ in a humidified $5 \% \mathrm{CO}_{2}$ incubator. To determine the transfection efficiency, the number of transfected cells was divided by the total number of cells and the enrichment or selection using G418 antibiotic was carried out.

\section{G418 concentration selection}

The wild-type (WT) i.e. untransfected 4T1 cells were plated at low density ( $\leq 10 \%$ confluence) in complete RPMI 1640 medium in 96-well plates in triplicates. Different concentrations (0, 100, 200, 400, 600,800 or $1000 \mu \mathrm{g} / \mathrm{mL}$ ) of G418, an antibiotic, were added to these cells and the plate was incubated at $37{ }^{\circ} \mathrm{C}$ for three days in a humidified $5 \% \mathrm{CO}_{2}$ incubator. The period of three days was chosen as it coincided with the WT-4T1 cells reaching confluence in the absence of G418. After three days, the culture medium from each well was removed and replaced with a complete fresh medium $(100 \mu \mathrm{L})$ and cell viability was measured using the MTT assay (Millipore, USA). The absorbance of each well at 570 $\mathrm{nm}$ was measured, and the percentage viability of cells was calculated. The minimum concentration of the G418 antibiotic that killed all the 4T1 cells was identified to be used for selection purposes. 


\section{Enrichment of transfected $4 T 1$ cells using G418} antibiotic

The 4T1 cells transfected with shRNA1, shRNA2, shRNA3, shRNA4 or shRNA5 (negative control) were subjected to an enrichment step using $200 \mu \mathrm{g} / \mathrm{mL}$ of G418. Briefly, the WT-4T1 cells were cultured in triplicates in a 24 -well plate until they reached confluence. Then, the cells were treated with $200 \mu \mathrm{g} / \mathrm{mL}$ of G418. The WT-4T1 cells cultured in the absence of the antibiotic were used as a control. The cells were incubated for three days at $37{ }^{\circ} \mathrm{C}$ in a humidified $5 \% \mathrm{CO}_{2}$ incubator. Following this, the culture medium from each well was removed and replaced with a complete fresh medium $(1 \mathrm{~mL})$. The cells were allowed to grow for $72 \mathrm{~h}$ before they were transferred into T75 flasks. Following this, the cells were cultured for another two weeks; after which some cells were cryopreserved (1\% DMSO, 1\% FBS). Some of the cells were used for RNA extraction to evaluate the expression of the SATB1 gene using quantitative PCR (qPCR). The transfected 4T1 cells showed the best inhibition (more than $70 \%$ ) of the SATB1 gene expression and were selected for further analysis.

\section{Evaluating the tumourigenicity of SATB1-deficient $4 \mathrm{~T} 1$ cells in a mouse model}

Five to eight-week-old inbred female BALB/C mice $(n=36)$ were purchased from an accredited supplier (Taconic Biosciences). The animals were housed at the Preclinical Research Facility (PCRF) at the Malaysian Palm Oil Board (MPOB) under standard laboratory conditions following the American Institute of Nutrition's recommendation for growing laboratory rodents (AIN-93G) with ad libitum. The mice had unlimited access to a commercial pellet diet (Supplement 3) and water. The animals were kept at a $12 \mathrm{~h}$ light/dark cycle at $20{ }^{\circ} \mathrm{C}-23^{\circ} \mathrm{C}$. This study was conducted following international animal ethics guidelines and was approved by the Joint Committee for Research and Ethics, International Medical University (IMU), Kuala Lumpur (IMU142/2007; Ref: 4.9/55/2007). After acclimatization, the mice were assigned randomly into one of the six study groups with six mice per group (Supplement 4). The mice were inoculated with $50 \mathrm{~mL}$ ( $1 \times 10^{3}$ cells) of either the WT-4T1 cells or the SATB1-knocked down 4T1 cells (SATB1-4T1) in their right flank mammary pad, as described previously (Abdul Hafid et al., 2010; 2013; 2019). The SATB1- 4T1 cells generated using shRNA1 were used for the in vivo study as this treatment produced the highest inhibition of the $S A T B 1$ gene.

The body weights of all animals were recorded every week. When the tumour was palpable (around day 12-14), the animals were assigned to vehicle or TRF-supplemented as well (Supplement 4). The mice in groups 1 and 4 did not receive any treatment and served as controls. The mice in groups 2 and 5 were fed daily with the vehicle from day 14 and given intramuscular (i.m.) injections of DC+TL on days 14, 21 , and 28. The mice in groups 3 and 6 were fed daily with TRF (1 mg/day) from day 14 and given intramuscular (i.m.) injections of DC+TL on days 14 , 21 and 28 (Supplement 4). Tumour volume was measured using a calliper once every seven days. Tumour growth was monitored by measuring the tumour length and width with callipers and calculating the tumour volume according to the formula $\mathrm{V}=(\mathrm{L} \times \mathrm{W} 2) / 2[\mathrm{~W}$ : tumour width; $\mathrm{L}$ : tumour length] (Abdul-Hafid et al., 2010, 2013). The mice were humanely euthanized when the study ended in week 9.

\section{Histopathology studies}

At autopsy, the tumour tissue was removed from the animals by cutting the tissues around the tumour using scissors and the tumour was retrieved using forceps. Then, half of the tumour tissue was snap-frozen in liquid nitrogen and stored at $-80{ }^{\circ} \mathrm{C}$ for gene expression studies, and the other half was stored in 10\% PBS-formalin solution for histopathology analysis. The lungs and liver were also harvested and stored in $10 \%$ formalin. The tissues stored in $10 \%$ formalin were processed using a tissue processor (Surgipath, Leica Biosystems, Germany), cut into thin sections, and stained with haematoxylin and eosin (H\&E) stains.

\section{Cytokine production}

A single-cell suspension was made from the spleen that was aseptically removed from each mouse and cultured in the presence of Concanavalin A (Con A) (Sigma, USA) for $24 \mathrm{~h}, 48 \mathrm{~h}$ or $72 \mathrm{~h}$. At the end of each cultured period, the supernatant from each spleen culture was collected to estimate interferongamma (IFN- $\gamma$ ) and interleukin-12 (IL-12) cytokines to induce a cell-mediated immune response required to fight cancers. The cytokines were quantified using suitable enzyme-linked immunosorbent assay (ELISA) kits (eBiosciences, USA).

Expression of SATB1, Metastatic, E-cadherin, Bcatenin and mutant p53 genes in tumours excised from the experimental mice

The total RNA was extracted from the portion of the tumour snap-frozen in liquid nitrogen using an RNA extraction kit (Qiagen, Germany). The extracted RNA was used for quantifying the expression of SATB 1, E-cadherin, B-catenin and mutant p53 genes and housekeeping genes (Andrechek et al., 2004; Naaman et al., 2004; Criswell \& Arteaga, 2007; $\mathrm{Wu}, 2007)$ using the quantitative PCR (qPCR) method. These genes were chosen based on previous cell-based studies (Abdul-Hafid et al., 2013, 2019). The extracted RNA was quantified using NanoDrop 
(NanoDrop ND1000 spectrophotometer, USA), and qPCR was performed as described previously (IQ5, BioRad, USA). Briefly, complementary DNA (cDNA) was synthesized from the total RNA using the reverse transcriptase (RT) approach with Superscript II (Invitrogen, USA) and deoxyribonucleotide triphosphate (dNTP) mix (Invitrogen, USA). PCR amplified the cDNA under the following conditions: $94{ }^{\circ} \mathrm{C}$ for 5 min followed by $94{ }^{\circ} \mathrm{C}$ for $60 \mathrm{~s}, 50{ }^{\circ} \mathrm{C}$ for $30 \mathrm{~s}, 72{ }^{\circ} \mathrm{C}$ for $30 \mathrm{~s}$, and the final extension step $72{ }^{\circ} \mathrm{C}$ for $7 \mathrm{~min}$ for 30 cycles. The primers used are listed in Table 1.

\section{Statistical analysis}

Statistical analysis was performed using SPSS version 20. Most of the data represented the means \pm SD of triplicate measurements. The qPCR data represented the means value with $\pm \mathrm{SEM}$ of triplicate measurements. The data obtained were analysed using one-way analysis of variance (ANOVA) with the Tukey post-hoc test and Alpha set at 0.05 $(p<0.05)$. For Figures 3 and 4 , the Two-Way ANOVA was used with the WEEKS/TIME as within-subjects factor and GROUPS as between-subjects factor.

\section{RESULTS}

\section{Generation of shRNA plasmid for transfection}

The shRNA approach using the Sure Silencing shRNA plasmids were used to generate stable SATB1-knocked down 4T1 cells (SATB1-4T1) using a commercial kit (QIAGEN, Germany). The transformation of E. coli competent cells (Promega,
USA) was successfully carried out using the four types of shRNA ( shRNA 4) and one positive control (shRNA control), which was the shRNA plasmids provided with this kit. The total amount of plasmid DNA obtained from the transformed bacterial single for each shRNA plasmid is shown in Supplement 5. The amount of DNA plasmid required for successful transfection of the 4T1 murine mammary cancer cells was calculated for each shRNA (Supplement 5).

\section{Determination concentrations of G418 to select the transfected $4 \mathrm{~T} 1$ cells}

Neomycin or G418 neomycin (Gibco, USA) is an antibiotic used to select stable SATB1-4T1 cells. A selection medium containing $600 \mathrm{mg} / \mathrm{mL}$ of $\mathrm{G} 418$ killed $46 \%$ of the shRNA transfected $4 \mathrm{~T} 1$ cells (Figure 1). Therefore, this concentration of G418 was selected to be used in the subsequent enrichment step.

\section{Knockdown of $S A T B 1$ gene in $4 \mathrm{~T} 1$ cells using ShRNA}

The highest inhibition of the SATB1 gene in the transfected 4T1 cells was observed with the shRNA 1 plasmid ( 0.225 -fold) followed by shRNA 3 (0.551-fold), shRNA 4 (0.784-fold) and shRNA 2 (0.941) (Figure 2). Based on this data, the shRNA 1 plasmid was chosen to knock down the $S A T B 1$ gene in the 4T1 cells to generate stable SATB1-4T1 cells, which would be tested in a syngeneic mouse model of breast cancer. However, it should be noted that we did not achieve a complete knock-down of the SATB1 gene in the SATB1-4T1 as we observed a low

Table 1. Primers used for the $q R T-P C R$

\begin{tabular}{|c|c|c|c|}
\hline \multirow{3}{*}{$\frac{\text { Gene (Mouse) }}{\text { Mouse beta-actin }}$} & \multicolumn{2}{|c|}{ Primer Sequence (5' to 3') } & \multirow{3}{*}{$\begin{array}{l}\text { Reference } \\
\text { BioRad, USA }\end{array}$} \\
\hline & $\mathbf{F}$ & 5'-AACTCGAGTGCCATGGTAACCGTTGAGAC-3' & \\
\hline & $\mathbf{R}$ & 5'-AACTCGAGAGACTCCTCAGATGAAGTGTT-3' & \\
\hline \multirow[t]{2}{*}{ Mouse S100A4 (mts1) } & $\mathbf{F}$ & 5'-AACTCGAGTGCCATGGTAACCGTTGAGAC-3' & \multirow[t]{2}{*}{ Naaman et al., 2004} \\
\hline & $\mathbf{R}$ & 5'-AACTCGAGAGACTCCTCAGATGAAGTGTT-3' & \\
\hline \multirow[t]{2}{*}{ Mouse ERBB2 } & $\mathbf{F}$ & 5'-CCCAGATCTCCACTGGCTCC-3' & \multirow[t]{2}{*}{ Endrechek et al., 2004} \\
\hline & $\mathbf{R}$ & 5'-TTCAGGGTTCTCCACAGCACC-3' & \\
\hline \multirow[t]{2}{*}{ Mouse E-cadherin } & $\mathbf{F}$ & 5'-AATGGCGGCAATGCAATCCCAAGA-3' & \multirow[t]{2}{*}{ Criswell et al., 2007} \\
\hline & $\mathbf{R}$ & 5'-TGCCACAGACCGATTGTGGAGATA-3' & \\
\hline \multirow[t]{2}{*}{ Mouse B-catenin } & $\mathbf{F}$ & 5'-TTAAACTCCTGCACCCACCAT-3' & \multirow[t]{2}{*}{ Wu et al., 2007} \\
\hline & $\mathbf{R}$ & 5'-AGGGCAAGGTTTCGAATCAA-3' & \\
\hline \multirow[t]{2}{*}{ Mp53 } & $\mathbf{F}$ & 5'-AAAACCACTTGATGGAGAGTATTTCA-3' & \multirow[t]{2}{*}{ Wu et al., 2007} \\
\hline & $\mathbf{R}$ & 5'-GCTCCCGGAACATCTCGAA-3' & \\
\hline \multirow[t]{2}{*}{ SATB1 } & $\mathbf{F}$ & 5'-ACACAGCTCTGCTGCCCAAGCC-3' & \multirow[t]{2}{*}{ BioRad, USA } \\
\hline & $\mathbf{R}$ & 5'-GACCAGCTGAGGACTGATCGG-3' & \\
\hline
\end{tabular}

F: Forward; R: ReverseERBB2: Receptor tyrosine kinase 2; S100A4 (mts1): S100 calcium binding protein A4: Mp53: mutant p53; SATB1: special AT-rich sequence-binding protein 1. 


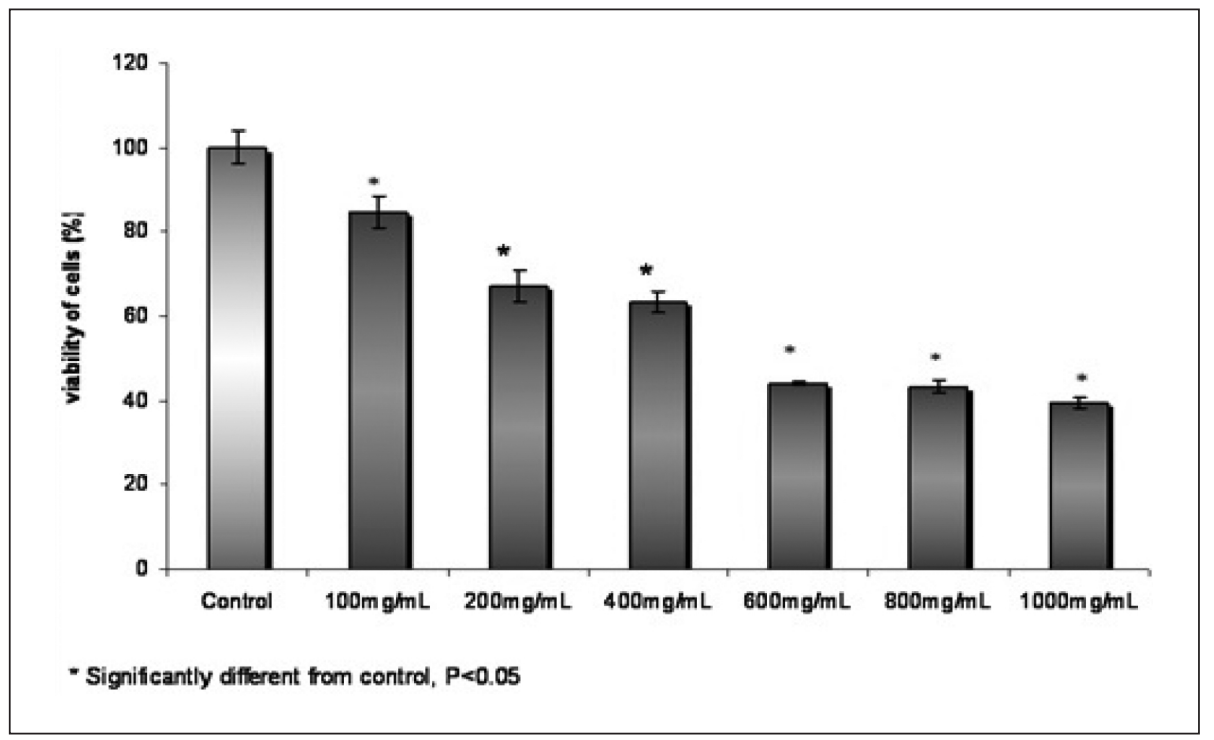

Fig. 1. The 4T1 murine mammary cancer cells were plated in triplicate wells of 12 -well plates and cultured in the presence of different concentrations $(0-1000 \mathrm{mg} / \mathrm{mL})$ of a selection antibiotic (G418) for $72 \mathrm{~h}$ at $37{ }^{\circ} \mathrm{C}$ in a humidified $5 \% \mathrm{CO}_{2}$ incubator. Cell viability was determined using the MTT assay. $P<0.05$, post-hoc test, Tukey Alpha.

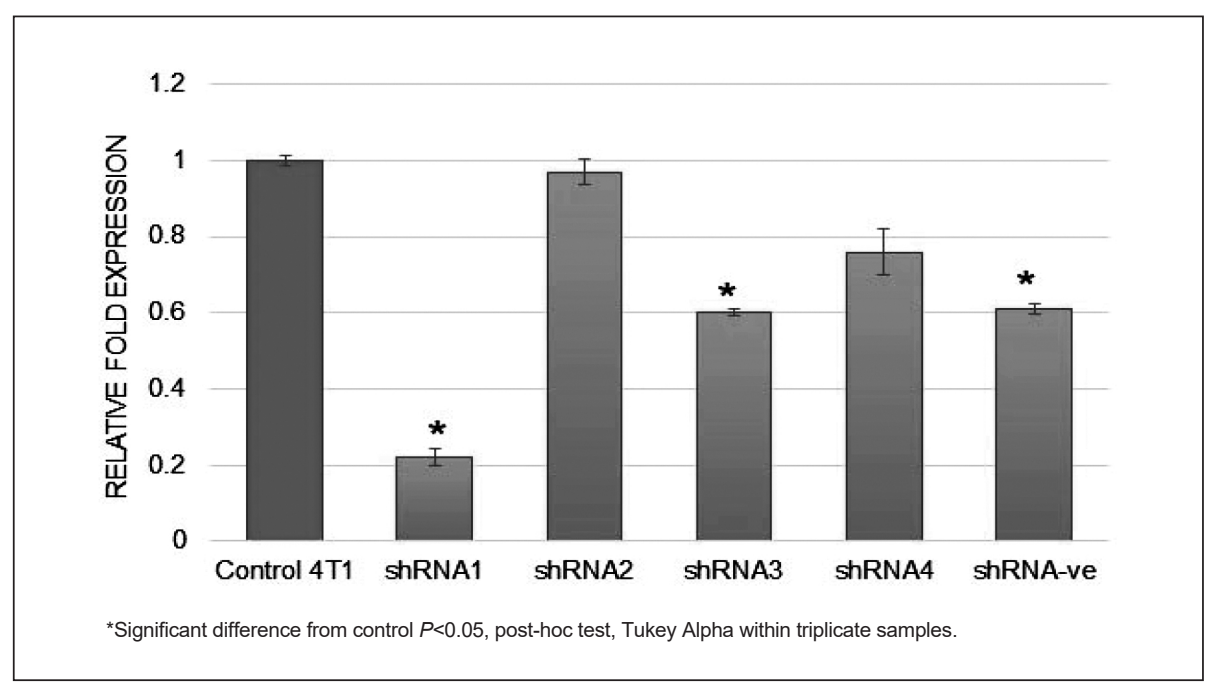

Fig. 2. The short hairpin (shRNA) technology was used to construct plasmids that could knock down the expression of SATB1 in 4T1 cells. The 4T1 cells were transfected with the different shRNA preparations (shRNA control, shRNA 1, shRNA 2, shRNA 3 and shRNA 4). After transfection, RNA was extracted from the transfected cells and was analysed using real-time PCR to detect the presence of the SATB1 gene.

expression of the SATB1 gene remaining in these knocked down cells.

\section{Tumourigenicity of the $S A T B 1$-deficient 4 T1 cells in a mouse model}

The size of primary tumours in all mice was recorded once a week (Figure 3). The mean tumour volume of mice injected with SATB1-4T1 cells fed with vehicle (Soy oil) was $155.17 \mathrm{~mm}^{3}$, was smaller $(p<0.05$, Two-Way repeated ANOVA with WEEKS as within-subjects factor and GROUP as betweensubjects factor), than the corresponding group of mice injected with the WT-4T1 cells $\left(250.75 \mathrm{~mm}^{3}\right)$ measured (Figure 3). On the 9th week, the mean tumour volume recorded in the mice injected with WT-4T1 or SATB1-4T1 cells and treated with DC+TL was $75.77 \mathrm{~mm}^{3}$ and $45.54 \mathrm{~mm}^{3}$, respectively (Figure $3)$. In contrast, there was little difference in the mean tumour volume in TRF-fed mice injected with WTSATB1 $\left(12.0 \mathrm{~mm}^{3}\right)$ or SATB1-4T1 $\left(11.2 \mathrm{~mm}^{3}\right)$ cells and 


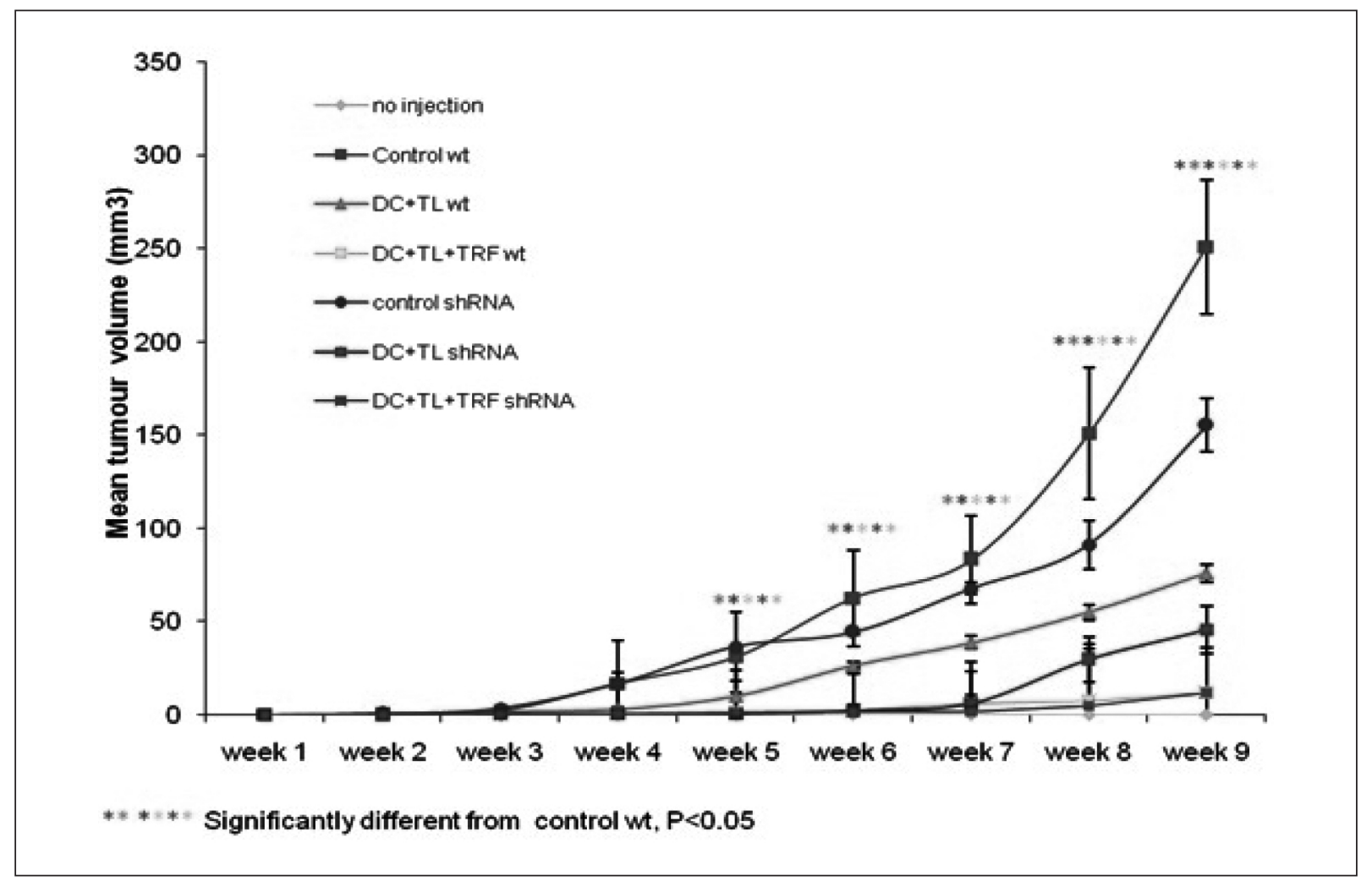

Fig. 3. Female BALB/c were inoculated with $1 \times 10^{3}$ of wild-type (4T1-WT) or SATB1-knocked down $4 \mathrm{~T} 1$ cells (4T1SATB1-) in their mammary pad to induce BC. When the tumour was palpable (day 14), the mice in the control groups (control) inoculated with either of the $4 \mathrm{~T} 1 \mathrm{cells}$ received oral gavage of $50 \mathrm{~L}$ of the vehicle (soy oil). The mice in the $\mathrm{DC}+\mathrm{TL}$ groups received three intramuscular injections of dendritic cells pulsed with tumour lysate from 4T1 cells (DC+TL) on days 14, 21 and 28. The mice in the DC+TL+TRF groups received three intramuscular injections of dendritic cells pulsed with tumour lysate from 4T1 cells on days 14, 21 and 28 and daily supplementation of $50 \mathrm{ml}$ of $1 \mathrm{mg}$ of TRF from day 14 (DC+TL+TRF). Tumour size was measured once a week using a digital calliper and calculated as described previously (Abdul Hafid et al., 2019).

[*: DC+TL wt; *: DC+TL+TRF wt; *: Control shRNA; *: DC+TL shRNA; *: DC+TL+TRF shRNA].

The test was run in Two-Way ANOVA with WEEKS as within-subjects factor and GROUP as between-subjects factor.

injected with DC+TL (Figure 3). In the DC+TL treated groups, there were about $39.8 \%$ differences (reduction) in the total mean tumour volume between the WT-4T1 or SATB1-4T1 injected mice. In contrast, there was only a $6.67 \%$ difference (reduction in SATB1-4T1 group) in the total mean tumour volume in the $\mathrm{DC}+\mathrm{TL}+\mathrm{TRF}$ treated groups.

\section{Productions of IFN-gamma and IL-12 by mitogen- stimulated splenocytes}

There was increased production of IFN- $\gamma$ $(p<0.05)$ by the Con A-stimulated splenocytes from mice injected with WT-4T1 $(162.70 \mathrm{pg} / \mathrm{mL})$ or SATB14T1 $(187.92 \mathrm{pg} / \mathrm{mL})$ cells that were treated with $\mathrm{DC}+\mathrm{TL}+\mathrm{TRF}$ compared to the $\mathrm{DC}+\mathrm{TL}$ treatment [WT-4T1 (125.86 pg/mL) and SATB1-4T1 (137.33 pg/ $\mathrm{mL})$ ] (Figure $4 \mathrm{a})$. In contrast, IFN- $\gamma$ produced by mitogen-stimulated splenocytes from vehicle-fed mice, i.e., the control groups were much lower [WT4T1 (46.04 pg/mL) and SATB1-4T1 (64.84 pg/ mL)], which was also lower than the amount produced by splenocytes from normal mice (Figure 4a). The production of IFN- $\gamma$ increased in a time-dependent manner. A similar increase $(p<0.05)$ was also observed in the production of IL-12 by the mitogen-stimulated splenocytes from mice injected with WT-4T1 (270.70pg/mL) or SATB1-4T1 (352.43 pg/mL) cells and treated with $\mathrm{DC}+\mathrm{TL}+\mathrm{TRF}$ when compared to mice that received the $\mathrm{DC}+\mathrm{TL}$ treatment [WT-4T1 (275.41 pg/mL) and SATB1-4T1 (225.86 pg/mL)] (Figure $4 \mathrm{~b}$ ). Production of IL-12 by mitogenstimulated splenocytes from vehicle-fed mice, i.e., the control groups were much lower [WT-4T1 (43.56 pg/ $\mathrm{mL})$ and SATB1-4T1 (45.38 pg/mL)], which was also lower than the amount produced by splenocytes from normal mice (Figure 4b). Additionally, the production of IL-12 also increased in a time-dependent manner. Overall, splenocytes from mice injected with SATB1$4 \mathrm{~T} 1$ cells and treated with DC+TL+TRF produced higher levels of both cytokines when compared to those injected with the WT-4T1 cells. 


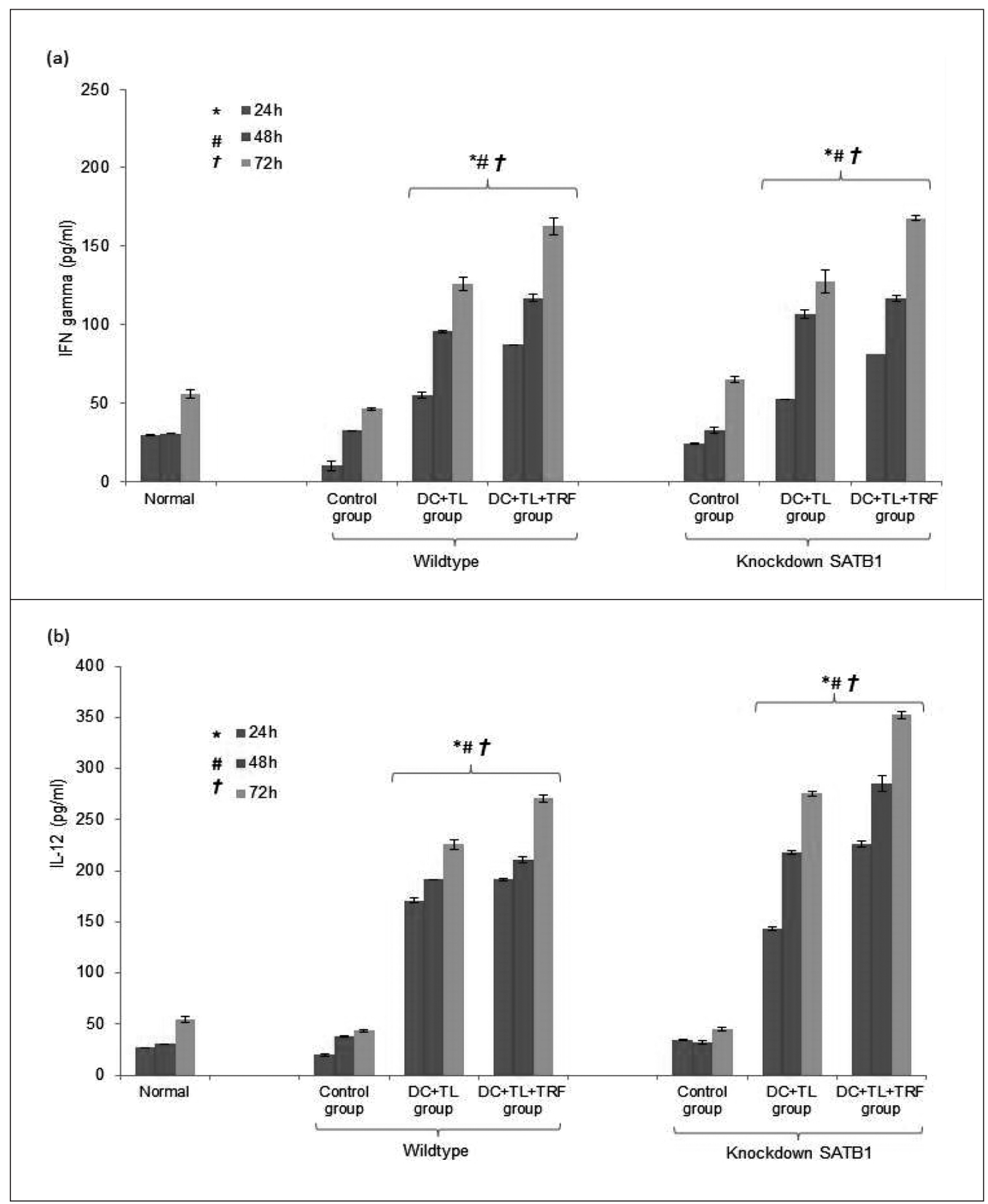

Fig. 4. Female BALB/c were inoculated with $1 \times 10^{3}$ of wild-type (4T1-WT) or SATB1-knocked down 4T1 cells (4T1 $\left.{ }^{\mathrm{SATB} 1}\right)$ in their mammary pad to induce BC. When the tumour was palpable (day 14), the mice in the control groups (control) were inoculated with either of the $4 \mathrm{~T} 1$ cells that received oral gavage of $50 \mathrm{~mL}$ of the vehicle (soy oil). The mice in the $\mathrm{DC}+\mathrm{TL}$ groups received three intramuscular injections of dendritic cells pulsed with tumour lysate from the 4T1 cell (DC+TL) on days 14, 21 and 28. The mice in the DC+TL+TRF groups received three intramuscular injections of dendritic cells pulsed with tumour lysate from 4T1 cell on days 14, 21 and 28 and daily supplementation of $50 \mathrm{~mL}$ of $1 \mathrm{mg}$ of TRF daily from day 14 (DC+TL+TRF). At the autopsy, splenocytes were harvested cultured in the presence of Con A for $24 \mathrm{~h}, 48$ $\mathrm{h}$ or $72 \mathrm{~h}$ at $37{ }^{\circ} \mathrm{C}$ in a humidified $5 \% \mathrm{CO}_{2}$ incubator. Splenocytes from normal mice (no injection) were included for comparison. The amount of (a) IFN- $\gamma$ and (b) IL-12 produced by these cells after $24 \mathrm{~h}, 48 \mathrm{~h}$ or $72 \mathrm{~h}$ were quantified using the commercial ELISA kits.

[*: $24 \mathrm{hr} ; \#: 48 \mathrm{hr} \dagger: 72 \mathrm{hr}$ ] Significantly different from control group (in $24 \mathrm{hr}, 48 \mathrm{hr} \& 72 \mathrm{hr}$ ), $\mathrm{P}<0.05$

The test was run in Two-Way ANOVA with TIME as within-subjects factor and GROUP as between-subjects factor. 


\section{Gene expression studies in excised tumours}

The expression of the SATB1 gene was lower in tumours excised from mice injected with the SATB14T1 cells (control: 0.147-fold; DC+TL: 0.073-fold; DC+TL+TRF: 0.034 -fold) compared to the tumours obtained from mice injected with the WT-4T1 cells (control: 1.0-fold; DC+TL: 0.77-fold; DC+TL+TRF: 0.56 -fold) (Figure 5a), which confirmed that the expression of the SATB1 gene in the SATB1-4T1 cells remained very low even when these cells developed into a tumour in the mice.

There was over-expression of the $S 1004 \mathrm{~A}$ gene in tumours from mice injected with WT-4T1 cells and fed with vehicle (control) (1.0-fold) or treated with $\mathrm{DC}+\mathrm{TL}$ (0.841-fold) (Figure 5b). However, the expression of the $S 1004 A$ gene was markedly reduced $(0.112$-fold $)$ in tumours from mice treated with $\mathrm{DC}+\mathrm{TL}+\mathrm{TRF}$ (Figure 6b). In contrast, it was observed that tumours from the mice injected with SATB1-4T1 cells showed marked suppression of the $S 1004 \mathrm{~A}$ gene in all groups (Control: 0.05-fold; DC+TL: 0.037- fold; DC+TL+TRF: 0.005-fold) (Figure 5b).

Tumours from mice injected with SATB1-4T1 cells and fed with vehicle (control) showed a marked reduction ( 0.26 -fold) of $m P 53$ gene compared to tumours from the control mice injected with WT-4T1 cells (1.0-fold) (Figure 5c). In contrast, there was a potent inhibition of $m P 53$ expression in tumours from mice treated with $\mathrm{DC}+\mathrm{TL}+\mathrm{TRF}$, regardless of which type of 4T1 cells (WT or SATB1-knocked down) were used to induce the tumour [WT-4T1 cells $(0.0041$ fold) and SATB1-4T1 cells (0.0061-fold)] (Figure 5c). Tumours from mice that received DC+TL treatment also showed a reduced expression of the $m P 53$ gene [WT-4T1 cells (0.26-fold) and SATB1-4T1 cells (0.24fold)] (Figure 5c).

The expression of the E-cadherin gene was upregulated $(p<0.05)$ in tumours obtained from the DC+TL (WT-4T1: 1.327-fold, SATB1-4T1: 1.576-fold) and DC+TL+TRF (WT-4T1: 1.457-fold, SATB1-4T1: 1.587 -fold) treated groups compared to their corresponding controls (WT-4T1: 1.0-fold, SATB1-

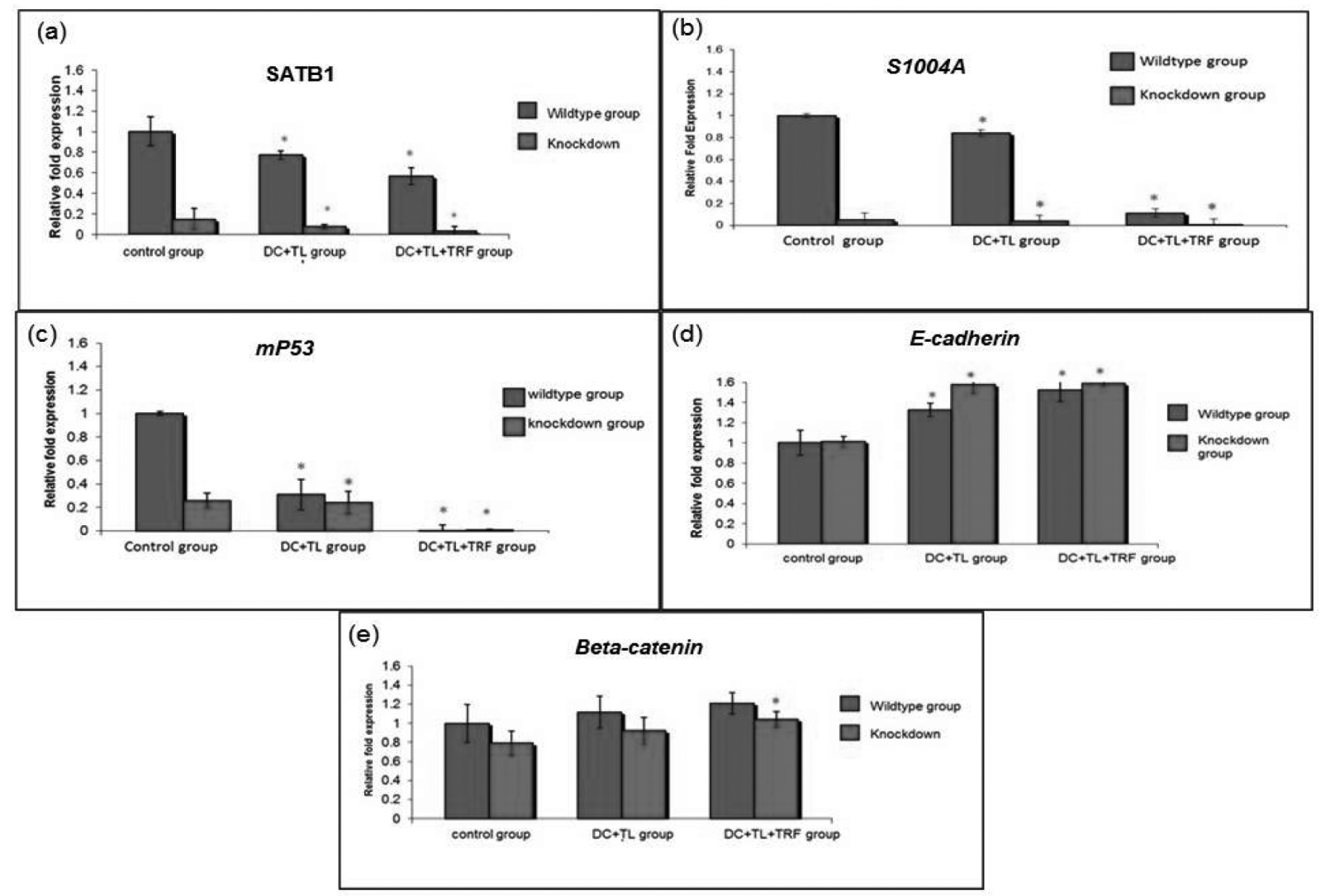

Fig. 5. Female BALB/c were inoculated with $1 \times 10^{3}$ of wild-type (4T1-WT) or SATB1-knocked down $4 \mathrm{~T} 1 \mathrm{cells}\left(4 \mathrm{~T} 1^{\mathrm{SATB}}\right.$ ) in their mammary pad to induce BC. When the tumour was palpable (day 14), the mice in the control groups (control) were inoculated with either of the $4 \mathrm{~T} 1$ cells that received oral gavage of $50 \mathrm{~mL}$ of the vehicle (soy oil). The mice in the $\mathrm{DC}+\mathrm{TL}$ groups received three intramuscular injections of dendritic cells pulsed with tumour lysate from the 4T1 cell (DC+TL) on days 14, 21 and 28. The mice in the DC+TL+TRF groups received three intramuscular injections of dendritic cells pulsed with tumour lysate from the 4T1 cell on days 14, 21 and 28 and daily supplementation of $50 \mathrm{~mL}$ of $1 \mathrm{mg}$ of TRF from day $14(\mathrm{DC}+\mathrm{TL}+\mathrm{TRF})$. At the autopsy, tumours were harvested and stored at $-80^{\circ} \mathrm{C}$ and RNA was extracted from the tumour samples. The expressions of the (a) SATB1; (b) $S 1004 A$, (c) $m P 53$, (d) E-cadherin and (e) beta-catenin genes were quantified using the real-time PCR approach.

(*Significantly different from the control group $p<0.05$, post-hoc test, Tukey Alpha within triplicate samples). 
4T1: 1.02-fold) (Figure 5d). Supplementation with TRF appeared to significantly $(p<0.05)$ enhance the $E$-cadherin gene expression compared to the control.

The expressions of the beta-catenin ( $\beta$-catenin) gene increased in tumours obtained from mice injected with the WT-4T1 cells from the DC+TL (1.117-fold) and DC+TL+TRF (1.21-fold) groups compared to the control mice (1.0-fold) (Figure 5e). In contrast, this gene expression decreased in the tumour obtained from the control group of mice injected with the SATB1-4T1 cells (0.79-fold) compared to WT-4T1 cells (1.0-fold). In tumours from the $\mathrm{DC}+\mathrm{TL}$ groups, the $\beta$-catenin gene expression was regulated in tumours induced by the WT-4T1 cells (1.117-fold) and SATB1-4T1 cells (0.921-fold). It appeared that the expression of the $\beta$-catenin gene decreased in tumours from the SATB1-4T1 cells.
There was a slight increase in the expression of the $\beta$-catenin gene (1.04-fold) in the tumours from mice injected with the SATB1-4T1 cells and treated with $\mathrm{DC}+\mathrm{TL}+\mathrm{TRF}$.

\section{Histopathological analysis of tumour, lungs and livers}

The microscopic sections of the lungs and livers obtained from the normal mice (no injection) showed normal liver morphology, such as hepatocytes within normal sinusoids, typical architecture of central veins and portal triads. The lung sections from these mice also show normal alveolar spaces with no evidence of abnormal morphology (Figure 6).

In the tumour sections from mice injected with the SATB1-4T1 cells (control knockdown), there were focal areas of necrosis in the primary tumour

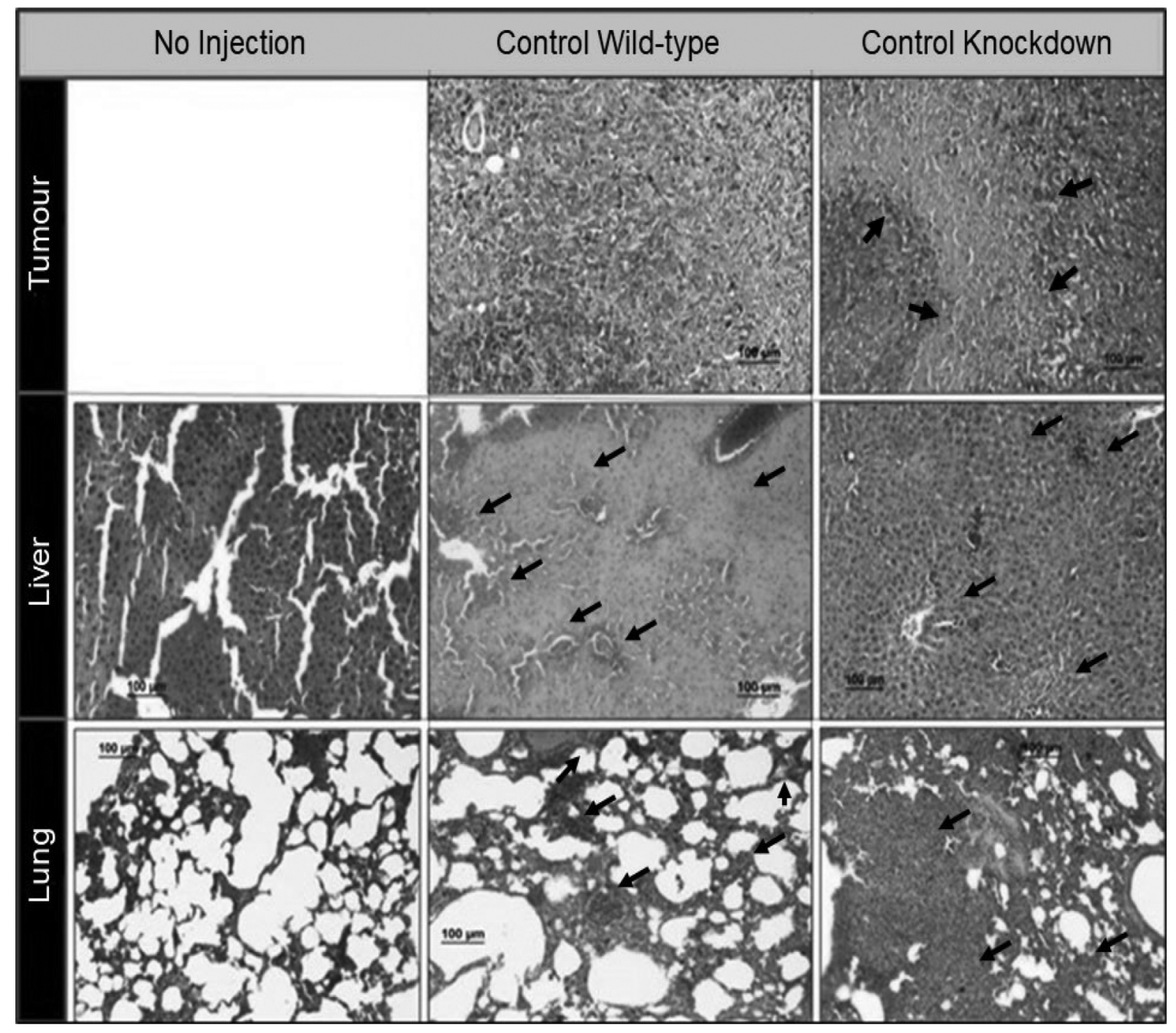

Fig. 6. Photomicrographs of haematoxylin and eosin (H\&E) stained sections of tumour, liver and lungs from normal mice (no injection), control mice injected with 4T1-WT (Control wild-type) or 4T1 SATB1- (Control knockdown) cells. The tissues were processed and stained with the H\&E stain and analysed using the Nikon Bright field compound microscope connected to a computer that enabled image capturing (NIS BR 3.0). The primary tumour section was used as a leading indicator of its characteristics. Typical morphology of liver and lungs tissues with no abnormalities was observed (200X, H\&E stain). Arrow in tumour indicates necrosis and arrow in liver and lung indicate metastasis. 
area within the clusters of neoplastic tissue (Figure $6)$. The liver sections showed small clusters of metastatic cells among the parenchyma and around the central vein. The tissue sections from the lungs and liver from the same mice showed a few scattered clusters of metastatic deposits (Figure 6). Lungs from mice injected WT-4T1 cells fed with vehicle (control WT) showed a large tumour, composed of round to oval cells with large prominent vesicular nuclei and a few areas of hyperchromatic nuclei. There were a few mitotic cells observed in the tissue sections. The cancer cells exhibited extensive pleomorphisms and were arranged in sheets and clusters, with no evidence of any capsules (Figure 6). Sections from these animals' lungs showed a few scattered clusters of metastatic deposits among the alveolar regions. Numerous clusters were irregular in shape and composed of cells that appeared to have the exact nature of the primary tumour.

Photomicrographs of H\&E stained tissue sections from experimental mice injected with WT4T1 cells and treated with DC+TL showed that the primary tumour had the same features observed in the untreated mice, such as tumours composed of round to oval cells with large prominent vesicular nuclei and a few areas of hyperchromatic nuclei were present (Figure 7). The cells exhibited extensive pleomorphisms and were arranged in sheets and clusters, with no evidence of any capsules (Figure 7). However, there were some areas of necrosis observed. In this animal, the sections from the lungs and liver showed normal morphology. For tumours from mice treated with $\mathrm{DC}+\mathrm{TL}+\mathrm{TRF}$, the primary tumour tissue predominantly showed areas of

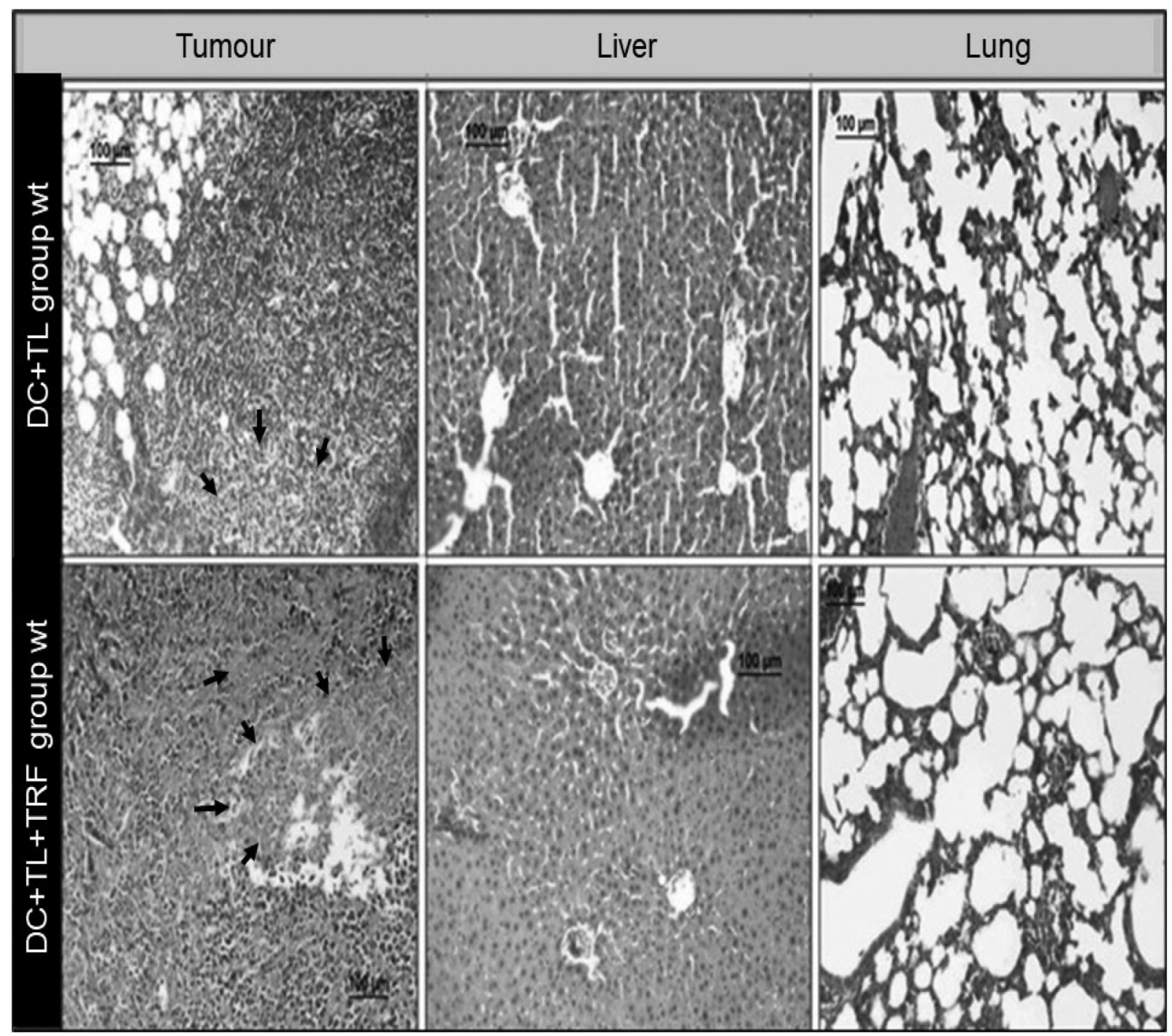

Fig. 7. Photomicrographs $(200 \mathrm{X})$ of H\&E-stained sections of tumour, liver and lungs from mice injected with 4T1-WT cells and treated with either DC+TL or DC+TL+TRF.

[DC+TL mice injected with 4T1-WT cells and received three injections of DC pulsed with tumour lysate (TL) from 4T1 cells; DC+TL+TRF: mice that were injected with 4T1-WT cells and received three injections of DC+TL and supplemented with TRF daily]. Arrow in tumour indicates necrosis. 


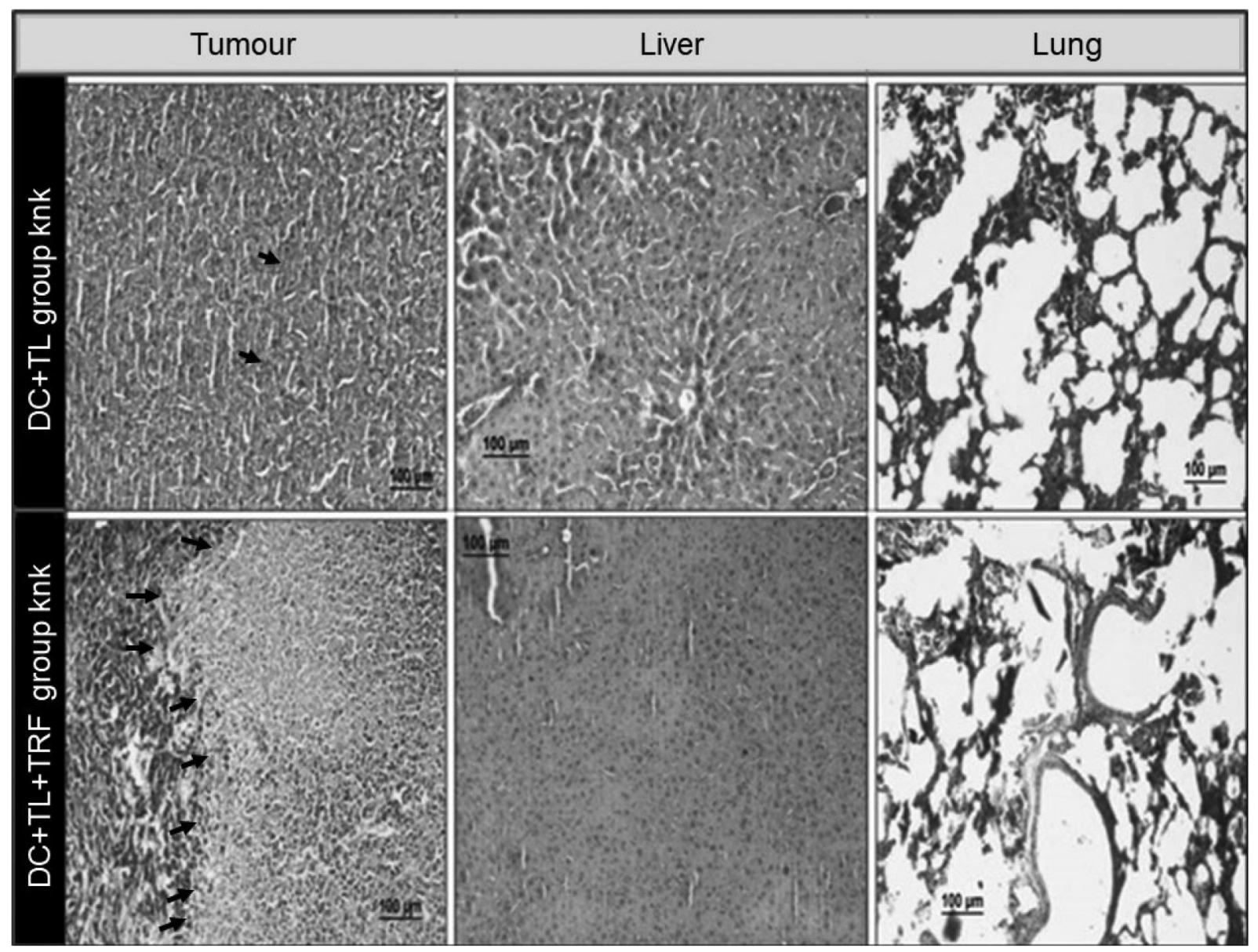

Fig. 8. Photomicrographs $(200 \mathrm{X})$ of H\&E-stained sections of tumour, liver and lungs from mice injected with 4 T1 ${ }^{\text {SATB1- }}$ (knk) cells and treated with either DC+TL or DC+TL+TRF. DC+TL mice injected with 4T1-knk cells and received three injections of DC pulsed with tumour lysate (TL) from the 4T1 cells; DC+TL+TRF: mice injected with 4T1-knk cells and received three injections of DC+TL and supplemented with TRF daily]. Arrow in tumour indicates necrosis.

necrotic tissue with scattered islands of poorly differentiated carcinoma (Figure 7). The liver and lungs showed typical architecture with no evidence of metastatic tissue.

Photomicrograph of H\&E stained tissue sections from mice injected with the SATB1-4T1 cells and treated with $\mathrm{DC}+\mathrm{TL}$ showed that the primary tumour had poorly differentiated cells, of which the cells were round to oval in shape with the presence of large hyperchromatic nuclei with an abundant and eosinophilic cytoplasm (Figure 8). Microscopic sections from the lung and liver tissues from these animals showed typical morphologies.

The primary tumour from the $\mathrm{DC}+\mathrm{TL}+\mathrm{TRF}$ treated group showed extensive areas of tissue necrosis and minimal peripheral cuff of residual tumour cells, which exhibited pleomorphism. The microscopic sections of lung tissues from these mice showed typical architecture with occasional inflammation in the alveoli, while the liver sections showed mild congestion around the central veins with normal-looking hepatocytes and sinusoids.

\section{DISCUSSION}

Supplementation with TRF was reported to downregulated the expression of the SATB1 gene in 4T1 cells (Abdul-Hafid et al., 2019). Hence, we generated stable 4T1 cells that are deficient in SATB1 expression (SATB1-4T1) to evaluate the effect of this gene using cell-based analysis and in a syngeneic mouse model of BC.

The SATB 1 gene is reported to be involved in the regulation of many genes involved in promoting metastasis in BC cells (Han et al., 2008). Inhibiting the expression of the $S A T B 1$ gene inhibited tumour growth and reversed the metastatic phenotypes in aggressive BC cells (Han et al., 2008); which demonstrates the critical role played by the $S A T B 1$ gene in BC's progression. There was a significant delay in tumour growth in the mice injected with SATB1-4T1 cells. Furthermore, tumours from the SATB1-4T1 injected mice were smaller $(p<0.05)$ when compared to tumours from animals injected with the WT-4T1 cells, which strongly suggested that the 
Supplement 1. Plasmid DNA concentration

\begin{tabular}{lccc}
\hline $\begin{array}{l}\text { Plasmid DNA } \\
\text { (shRNA) }\end{array}$ & $\begin{array}{c}\text { Concentration } \\
(\mu \mathrm{g} / \mu \mathrm{L})\end{array}$ & $\begin{array}{c}\text { Volume for } 3.2 \mu \mathrm{g} \\
\text { of DNA plasmid }\end{array}$ & $\begin{array}{c}\text { Total volume } \\
\text { (Volume of TE buffer to be used } \\
\text { to get 2.2 } \mathrm{mL} \text { of total volume) }\end{array}$ \\
\hline shRNA (Negative Control) & $2.22 \mu \mathrm{g} / \mu \mathrm{L}$ & $1.44 \mu \mathrm{L}$ & $0.76 \mu \mathrm{L}$ \\
shRNA 1 & $3.72 \mu \mathrm{g} / \mu \mathrm{L}$ & $0.86 \mu \mathrm{L}$ & $1.34 \mu \mathrm{L}$ \\
ShRNA 2 & $4.53 \mu \mathrm{g} / \mu \mathrm{L}$ & $0.71 \mu \mathrm{L}$ & $1.49 \mu \mathrm{L}$ \\
shRNA 3 & $3.62 \mu \mathrm{g} / \mu \mathrm{L}$ & $0.88 \mu \mathrm{L}$ & $1.32 \mu \mathrm{L}$ \\
shRNA 4 & $1.69 \mu \mathrm{g} / \mu \mathrm{L}$ & $1.89 \mu \mathrm{L}$ & $0.31 \mu \mathrm{L}$ \\
\hline
\end{tabular}

Supplement 2. The layout for treatment in the 24-well plates.
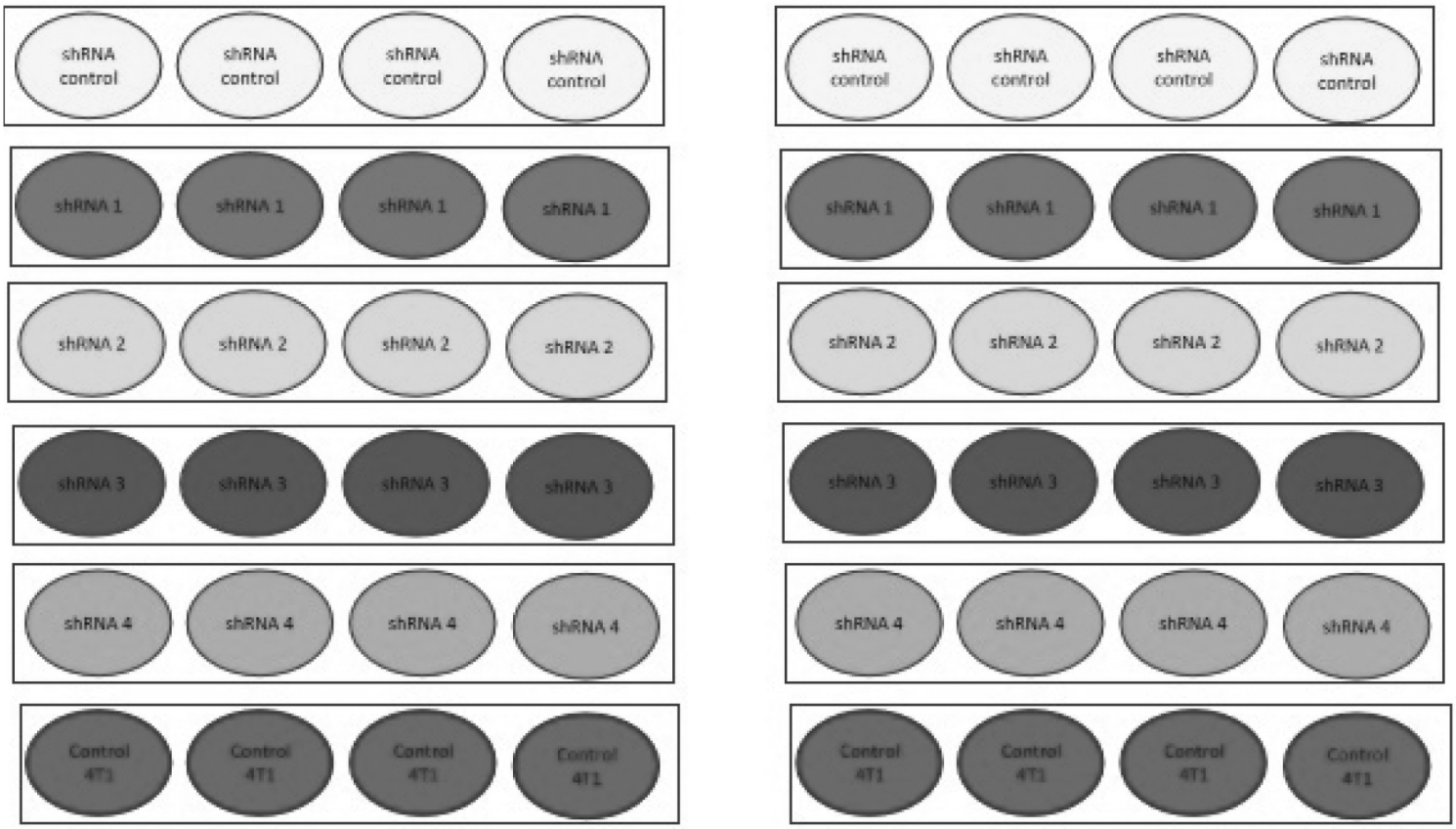

Supplement 3. Standard normal chow (diet) in maintaining mice purchased from Altromin (Lage, Germany, diet 1324)

\begin{tabular}{lcr}
\hline \multicolumn{3}{c}{ Metabolised energy } \\
\hline Content & value & Unit \\
\hline Fat & $367(11 \%)$ & $\mathrm{kcal} / \mathrm{kg}$ \\
Protein & $768(24 \%)$ & $\mathrm{kcal} / \mathrm{kg}$ \\
Carbohydrates & $2,091(65 \%)$ & $\mathrm{kcal} / \mathrm{kg}$ \\
\hline \multicolumn{4}{c}{ Crude nutrients and moisture } & \\
\hline Content & value & Unit \\
\hline Moisture & $113,426(11.3 \%)$ & $\mathrm{mg} / \mathrm{kg}$ \\
Crude Ash & $58,553(5.9 \%)$ & $\mathrm{mg} / \mathrm{kg}$ \\
Crude Fibre & $60,744(6.1 \%)$ & $\mathrm{mg} / \mathrm{kg}$ \\
Crude fat & $40,791(4.1 \%)$ & $\mathrm{mg} / \mathrm{kg}$ \\
Crude Protein & $192,111(19.2 \%)$ & $\mathrm{mg} / \mathrm{kg}$ \\
Nitrogen free extractives & $534,374(53.4 \%)$ & $\mathrm{mg} / \mathrm{kg}$ \\
\hline
\end{tabular}


Supplement 4. Group of mice in the knocked-down study

\begin{tabular}{|c|c|c|c|}
\hline $4 \mathrm{~T} 1$ cells & Group & Treatment & $\begin{array}{l}\text { Number } \\
\text { of mice }\end{array}$ \\
\hline \multirow[t]{3}{*}{ Wild-type } & 1 & Fed with vehicle (soy oil) & 6 \\
\hline & 2 & Received three i.m. injections of DC+TL\# on days 14,21 and 28 & 6 \\
\hline & 3 & $\begin{array}{l}\text { Received three i.m. injections of DC+TL\# on days } 14,21 \text { and } \\
28 \text { and daily supplementation with } 1 \mathrm{mg} \text { TRF }\end{array}$ & 6 \\
\hline \multirow{3}{*}{ SATB1-knocked-down } & 4 & Fed with vehicle (soy oil) & 6 \\
\hline & 5 & Received three i.m. injections of $\mathrm{DC}+\mathrm{TL}^{*}$ on days 14,21 and 28 & 6 \\
\hline & 6 & $\begin{array}{l}\text { Received three i.m. injections of } \mathrm{DC}+\mathrm{TL}^{*} \text { on days } 14,21 \text { and } \\
28 \text { and daily supplementation with } 1 \mathrm{mg} \text { TRF }\end{array}$ & 6 \\
\hline
\end{tabular}

DC: dendritic cells; i.m.: intra-muscular; shRNA: short hairpin RNA; TL: tumour lysate from 4T1 cells: TRF: tocotrienol-rich fraction\#: TL from wild-type 4T1 cells; *: TL from SATB1-knocked down 4T1 cells.

SATB1 gene plays a crucial role in tumorigenesis in this model; therefore, the research hypothesis is accepted. In addition, feeding mice injected with the SATB1-4T1 cells did not augment the response observed. These findings strongly suggest that TRF may work through the SATB1 gene.

The production of IFN- $\gamma$ and IL-12 by splenocytes from mice injected with SATB1-4T1 cells increased in all groups (control, DC+TL and $\mathrm{DC}+\mathrm{TL}+\mathrm{TRF}$ ) compared to splenocytes from animals injected with the WT-4T1 cells. Both IFN- $\gamma$ and IL-12 promote T-helper-1 (TH1) immune responses that promote cell-mediated responses, including activation of tumour-specific cytotoxic T-lymphocyte (CTL) responses (Brossart \& Bevan, 1997; Puddu et al., 1997; Wu et al., 2001; Sato \& Nishimura, 2003; Lacroix, 2013; Teng et al., 2015). Interferon-gamma supports lymphocytes to protect against tumour development and sculpt the immunogenic phenotype of tumours that develop in an immunocompetent host, known as the "cancer immunoediting" process (Brossart \& Bevan, 1997; Puddu et al., 1997; Zhu et al., 2003; Lacroix, 2013; Teng et al., 2015). The IL-12, produced by DC and macrophage, is a T-cell stimulating factor (Herr et al., 2000; Zhu et al., 2003; Walzer et al., 2005). Also, IL-12 could stimulate the production of IFN-ã and tumour necrosis factor-alpha (TNF- $\alpha$ ) by T-lymphocytes and NK cells (Austyn, 1996; Brossart \& Bevan, 1997; Herr et al., 2000; Lacroix, 2013), as well as augment the cytotoxic activity of CTLs (Puddu et al., 1997; Zhu et al., 2003).

There was marked down-regulation of $51004 \mathrm{~A}$ and $m p P 53$ genes in tumours harvested from mice treated with $\mathrm{DC}+\mathrm{TL}+\mathrm{TRF}$, irrespective of the type of $4 \mathrm{~T} 1$ cells used to induce BC. In contrast, the expression of the $\beta$-catenin gene was higher in tumours from mice injected with WT-4T1 cells compared to those injected with SATB1-4T1 cells. In addition, TRF supplementation increased the expression of the $\beta$-catenin gene in tumours from mice injected with WT-4T1 or SATB1-4T1 cells. Betacatenin is a critical member of the canonical Wnt pathway, whilst E-cadherin is an adherent junction protein and tumour suppressor genes (Alvarez et al., 2000; Han et al., 2008; Zheng, 2008).

The expression of the E-cadherin gene was increased in the tumours from mice injected with the SATB1-4T1 cells when compared to tumours from mice injected with the WT-4T1 cells in the control and treatment groups. Loss of E-cadherin is a hallmark for EMT, a process whereby epithelial cells lose polarity, cell-to-cell contacts and cytoskeletal integrity, contributing to the dissemination of carcinoma cells from epithelial tumours (Wen et al., 2005; Han et al., 2008; Patani et al., 2009). Knocking out the $S A T B 1$ gene resulted in increased expression of the E-cadherin gene and decreased expression of fibronectin and $E$-cadherin repressors such as SNAIL and SIP1 (Liu et al., 2008), which indicates a reversal of the EMT process, restoring its' acinarlike morphology (Han et al., 2008).

Lack of SATB1 gene expression also inhibited the invasiveness of tumour growth. Tumours from animals injected with WT-4Tcells and fed with vehicle (control) showed poorly differentiated adenocarcinoma of the breast with metastasis to the lungs and liver. This study observed clear and marked metastatic tumour cells in the liver and lungs tissues sections of tumour-induced mice. Tumours from the control group (i.e., injected with SATB1-4T1 cells) had areas of necrosis, and there were fewer metastases observed in the liver and lungs. In contrast, tumour sections from mice injected with WT-4T1 cells and treated with DC+TL showed fewer necrosis areas, which indicate that the neoplastic cells were undergoing damage and getting destroyed; whilst the lungs and liver sections showed normal morphology. In addition, tumour sections from mice injected with SATB1-4T1 cells and treated with $\mathrm{DC}+\mathrm{TL}$ showed a poorly differentiated tumour, but the lungs and liver appeared normal. Tumour 
sections from mice injected with WT-4T1 cells and treated with $\mathrm{DC}+\mathrm{TL}+\mathrm{TRF}$ showed extensive necrosis and reduced neoplastic cells. The lungs and liver appeared normal. In comparison, tumours from mice injected with SATB1-4T1 cells treated with $\mathrm{DC}+\mathrm{TL}+\mathrm{TRF}$ had vast necrotic areas with lower numbers of scattered neoplastic cells. Section of the liver and lungs showed normal morphology. There was reduced metastasis observed in mice injected with SATB1-4T1 cells, which was not an unexpected finding as to the expression of SATB1, whereby several studies had linked this gene to cancer aggressiveness and was reported to be responsible for tumour progressions (Cai et al., 2003; Han \& Kohwi-Shigematsu, 2006; Zheng, 2008; Hanker et al., 2011). Therefore, knocking out this gene reduced the invasiveness of the tumour, as shown in this study.

\section{CONCLUSION}

This study provided preliminary evidence, which suggests that TRF might work through modulation of the $S A T B 1$ gene pathway, as there were no additional effects observed in the mice injected with the SATB1-4T1 cells fed with TRF compared to the animals fed with the vehicle. In addition, the gene expression patterns of tumours from the TRF-treated mice appeared to correlate with the gene expression pattern observed in tumours from mice injected with SATB1-4T1 cells. However, there is a need to do further research to support these findings.

\section{ACKNOWLEDGEMENTS}

The authors would like to thank the Director-General of the Malaysian Palm Oil Board (MPOB) and International Medical University (IMU) for sponsoring this study. This work was supported by grants from the Malaysian Palm Oil Board PD119/08 and International Medical University (IMU 142/2007). This study was conducted following international animal ethics guidelines and was approved by the Joint Committee for Research and Ethics, International Medical University (IMU), Kuala Lumpur (IMU 142/2007; Ref: 4.9/55/2007).

\section{REFERENCES}

Abdul-Hafid, S.R., Chakravarthi, S., Nesaretnam, K. \& Radhakrishnan, A.K. 2013. Tocotrienoladjuvanted dendritic cells inhibit tumour growth and metastasis: A murine model of breast cancer. PLoS ONE, 8(9): p.e74753.
Abd-Hafid, S.R., Radhakrishnan, A.K. \& Chakravarthi, S. 2020. Silencing SATB1 gene Suppressed Expression of $m P 53$, S1004A Genes and Increased Expression of $\beta$-catenin and E-cadherin Genes in Murine Mammary Cancer Cells in the Presence and Absence of Tocotrienol-Rich Fraction (TRF). Journal of Cancer Studies and Therapy, 1(2): 45-54.

Abdul-Hafid, S.R. \& Radhakrishnan, A.K. 2019. Palm tocotrienol-adjuvanted dendritic cells decrease expression of the SATB1 gene in murine breast cancer cells and tissues. Vaccines, 7(4): 198.

Abdul-Hafid, S.R., Radhakrishnan, A.K. \& Nesaretnam, K. 2010. Tocotrienols are good adjuvants for developing cancer vaccines. $B M C$ Cancer, 10(5).

Abdurakhmonov, I.Y. 2016. RNA Interference - A Hallmark of Cellular Function and Gene Manipulation. IntechOpen.

Aggarwal, V., Kashyap, D., Sak, K., Tuli, H.S., Jain, A., Chaudhary, A., Garg, V.K., Sethi, G. \& Yerer, M.B. 2019. Molecular Mechanisms of Action of Tocotrienols in Cancer: Recent Trends and Advancements. International Journal of Molecular Sciences, 20(3): 656.

Ahmed, R.A., Alawin, O.A. \& Sylvester, P.W. 2016. $\gamma$-Tocotrienol reversal of epithelial-tomesenchymal transition in human breast cancer cells is associated with inhibition of canonical Wnt signalling. Cell Proliferation, 49(4): 460470.

Alvarez, J.D., Yasui, D.H., Niida, H., Joh, T., Loh, D.Y. \& Kohwi-Shigematsu, T. 2000. The MAR-binding protein $S A T B 1$ orchestrates temporal and spatial expression of multiple genes during T-cell development. Genes \& development, 14(5): 521535.

Andrechek, E.R., Hardy, W.R., Laing, M.A. \& Muller, W.J. 2004. Germ-line expression of an oncogenic erbB2 allele confers resistance to erbB2-induced mammary tumorigenesis. Proceedings of the National Academy of Sciences, 101(14): 4984-4989.

Austyn, J.M. 1996. New insights into the mobilisation and phagocytic activity of dendritic cells. The Journal of Experimental Medicine, 183(4): 1287-1292.

Brossart, P. \& Bevan, M.J. 1997. Presentation of exogenous protein antigens on major histocompatability complex class I molecules by dendritic cells: pathway of presentation and regulation by cytokines. Blood, The Journal of the American Society of Haematology, 90(4): 1594-1599. 
Cai, S., Han, H.J. \& Kohwi-Shigematsu, T. 2003. Tissue-specific nuclear architecture and gene expression regulated by SATB1. Nature Genetics, 34(1): 42-51.

Criswell, T.L. \& Arteaga, C.L. 2007. Modulation of $\mathrm{NF} \kappa \mathrm{B}$ activity and E-cadherin by the type III transforming growth factor â receptor regulates cell growth and motility. Journal of Biological Chemistry, 282(44): 32491-32500.

Deng, Y., Wang, C.C., Choy, K.W., Du, Q., Chen, J., Wang, Q., Li, L., Chung, T.K.H. \& Tang, T. 2014. Therapeutic potentials of gene silencing by RNA interference: Principles, challenges, and new strategies. Gene, 538(2): 217-227.

Han, H.J., Kohwi, Y. \& Kohwi-Shigematsu, T. 2006. $S A T B 1$ tethers multiple gene loci to reprogram expression profile driving breast cancer metastasis. Nature, 452(LBNL-60480).

Han, H.J., Russo, J., Kohwi, Y. \& Kohwi-Shigematsu, T. 2008. SATB1 reprogrammes gene expression to promote breast tumour growth and metastasis. Nature, 452(7184): 187-193.

Hanker, L.C., Karn, T., Mavrova-Risteska, L., Ruckhäberle, E., Gaetje, R., Holtrich, U., Kaufmann, M., Rody, A. \& Wiegratz, I. 2011. SATB 1 gene expression and breast cancer prognosis. The Breast, 20(4): 309-313.

Herr, W., Ranieri, E., Olson, W., Zarour, H., Gesualdo, L. \& Storkus, W.J. 2000. Mature dendritic cells pulsed with freeze-thaw cell lysates define an effective in vitro vaccine designed to elicit EBV-specific CD4+ and CD8+ T lymphocyte responses. Blood, The Journal of the American Society of Hematology, 96(5): 1857-1864.

Lacroix, M. 2013. A Concise History of Breast Cancer. Nova Science Publishers.

Ling, M.T., Luk, S.U. Luk, Al-Ejeh, F. \& Khanna, K.K. 2012. Tocotrienol as a potential anticancer agent, Carcinogenesis, 33(2): 233-239.

Liu, S., Ballian, N., Belaguli, N.S., Patel, S., Li, M., Templeton, N.S., Gingras, M.C., Gibbs, R., Fisher, W. \& Brunicardi, F.C. 2008. PDX-1 acts as a potential molecular target for treatment of human pancreatic cancer. Pancreas, 37(2): 210-220.

Naaman, C.E., Grum-Schwensen, B., Mansouri, A., Grigorian, M., Santoni-Rugiu, E., Hansen, T., Kriajevska, M., Schafer, B.W., Heizmann, C.W., Lukanidin, E. \& Ambartsumian, N. 2004. Cancer predisposition in mice deficient for the metastasis-associated Mts1 (S100A4) gene. Oncogene, 23(20): 3670-3680.

Nesaretnam, K., Meganathan, P., Veerasenan, S.D. \& Selvaduray, K.R. 2012. Tocotrienols and breast cancer: The evidence to date. Genes \& Nutrition, 7(1): 3-9.
Parveez, G.K.A., Hishamuddin, E., Loh, S.K., OngAbdullah, M., Salleh, K.M., Bidin, M.N.I.Z., Sundram, S., Hasan, Z.A.A. \& Idris, Z. 2020. Oil Palm economic performance in Malaysia and R\&D progress in 2019. Journal of Oil Palm Research, 32: 159-190.

Patani, N., Jiang, W., Mansel, R., Newbold, R. \& Mokbel, K. 2009. The mRNA expression of $S A T B 1$ and $S A T B 2$ in human breast cancer. Cancer Cell International, 9(1): 1-10.

Puddu, P., Fantuzzi, L., Borghi, P., Varano, B., Rainaldi, G., Guillemard, E., Malorni, W., Nicaise, P., Wolf, S.F., Belardelli, F. \& Gessani, S. 1997. IL-12 induces IFN-gamma expression and secretion in mouse peritoneal macrophages. The Journal of Immunology, 159(7): 490-3497.

Şalva, E., Ekentok, C., Turan, S.Ö. \& Akbuğa, J. 2016. Non-viral siRNA and shRNA Delivery Systems in Cancer Therapy. In: RNA Interference. I.Y. Abdurakhmonov (Ed.). IntechOpen.

Sato, M., Chamoto, K. \& Nishimura, T. 2003. A novel tumor vaccine cell therapy using bone marrow derived dendritic cell type 1 and antigen specific Th1 cells. International Immunology, 15(7): 837843.

Teng, M.W., Bowman, E.P., McElwee, J.J., Smyth, M.J., Casanova, J.L., Cooper, A.M. \& Cua, D.J. 2015. IL-12 and IL-23 cytokines: From discovery to targeted therapies for immune-mediated inflammatory diseases. Nature Medicine, 21(7): 719-729.

Walzer, T., Dalod, M., Robbins, S.H., Zitvogel, L. \& Vivier, E. 2005. Natural-killer cells and dendritic cells: "l'union fait la force". Blood, 106(7): 22522258.

Wen, J., Huang, S., Rogers, H., Dickinson, L.A., Kohwi-Shigematsu, T. \& Noguchi, C.T. 2005. SATB1 family protein expressed during early erythroid differentiation modifies globin gene expression. Blood, 105(8): 3330-3339.

WHO-World Health Organization: Breast Cancer [WWW document]. URL https//.www.who.int. breast cancer (accessed 6.6.20).

Wong, S.K., Kamisah, Y., Mohamed, N., Muhammad, N., Masbah, N., Mohd-Fahami, N.A., Mohamed, I.N., Shuid, A.N., Mohd-Saad, Q., Abdullah, A., Mohamad, N-V., Ibrahim, N.I., Pang, K-L., Chow, Y.Y., Thong, B.K.S., Subramaniam. S., Chan, C.Y., Ima-Nirwana, S. \& Chin, K-Y. 2020. Potential role of tocotrienols on non-communicable diseases: A review of current evidence. Nutrients, 12(1): 259. 
Wu, R.S., Kobie, J.J., Besselsen, D.G., Fong, T.C., Mack, V.D., McEarchern, J.A. \& Akporiaye, E.T. 2001. Comparative analysis of IFN- $\gamma$ B7. 1 and antisense TGF- $\alpha$ gene transfer on the tumorigenicity of a poorly immunogenic metastatic mammary carcinoma. Cancer Immunology, Immunotherapy, 50(5): 229-40.

Wu, Z.Q., Zhang, R., Connie, C., Zhang, J.F. \& Zhang, Y.Q. 2007. Histone deacetylase inhibitor trichostatin a induced caspase-independent apoptosis in human gastric cancer cell. Chinese Medical Journal, 120(23): 2112-2118.

Zhang, J., Li, X. \& Huang, L. 2014. Non-viral nanocarriers for siRNA delivery in breast cancer. Journal of Controlled Release, 190: 440450 .
Zhang, J.S., Zhang, S.J., Li, Q., Liu, Y.H., He, N., Zhang, J., Zhou, P-H., Li, M., Guan, T. \& Liu, J-R. 2015. Tocotrienol-rich fraction (TRF) suppresses the growth of human colon cancer xenografts in BALB/C nude mice by the Wnt pathway. PLoS ONE, 10(3): e0122175.

Zheng, J. 2008. Is SATB1 a master regulator in breast cancer growth and metastasis? Women's Health, 4(4): 329-332.

Zhu, C., Rao, K., Xiong, H., Gagnidze, K., Li, F., Horvath, C. \& Plevy, S. 2003. Activation of the murine interleukin-12 p40 promoter by functional interactions between NFAT and ICSBP. Journal of Biological Chemistry, 278(41): 39372-39382. 
